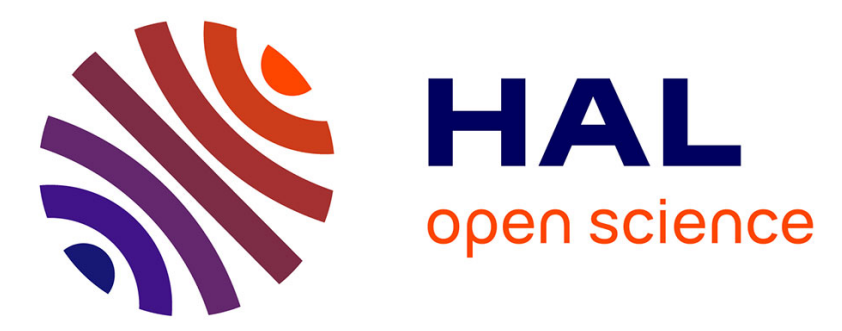

\title{
Is earthworms' dispersal facilitated by the ecosystem engineering activities of conspecifics?
}

Gael Caro, Anick Abourachid, Thibaud Decaens, Lorenza Buono, Jérôme Mathieu

\section{- To cite this version:}

Gael Caro, Anick Abourachid, Thibaud Decaens, Lorenza Buono, Jérôme Mathieu. Is earthworms' dispersal facilitated by the ecosystem engineering activities of conspecifics?. Biology and Fertility of Soils, 2012, pp.Online. 10.1007/s00374-012-0694-1 . bioemco-00712684

\section{HAL Id: bioemco-00712684 https://hal-bioemco.ccsd.cnrs.fr/bioemco-00712684}

Submitted on 27 Jun 2012

HAL is a multi-disciplinary open access archive for the deposit and dissemination of scientific research documents, whether they are published or not. The documents may come from teaching and research institutions in France or abroad, or from public or private research centers.
L'archive ouverte pluridisciplinaire HAL, est destinée au dépôt et à la diffusion de documents scientifiques de niveau recherche, publiés ou non, émanant des établissements d'enseignement et de recherche français ou étrangers, des laboratoires publics ou privés. 
1 Is earthworms' dispersal facilitated by the ecosystem engineering activities of conspecifics?

3 Gaël Caro $^{1 *}$, Anick Abourachid ${ }^{2}$, Thibaud Decaëns ${ }^{3}$,Lorenza Buono ${ }^{1}$, Jérôme Mathieu ${ }^{1}$ 4

5 1:UPMC Univ. Paris 06 - Bioemco, 46 rue d’Ulm, 75005, Paris, France

6 2: FRE2696, CNRS, MNHN, Univ. Paris 06, Collège de France, DépartementEcologie et

7 Gestion de la Biodiversité, Pavillon d'Anatomie Comparée, CP 55, 57 rue Cuvier, 75231

8 Paris cedex 05, France

9 3: Laboratoire d'Ecologie, EA 1293 ECODIV, FED SCALE, UFR Sciences et Techniques,

10 Université de Rouen, 76821 Mont Saint Aignan cedex, France

11

$12 *$ Corresponding author:

13 Gaël Caro

14 UMR Bioemco - ENS

1546 rue d'Ulm

1675005 Paris

17 France

18

19 E-mail: gael.c.caro@gmail.com

20 Tel : +33637972868

21 
25 In this work we documented the influence of earthworm's galleries on their speed of 26 movements during dispersal events in the soil. We quantified, by using X-rays, the dispersal 27 behaviour of earthworms in the soil. The observations were conducted in mesocosms in 28 controlled conditions during 12 hours. Our experiments revealed that during a dispersal 29 sequence of a batch of individuals of the species Aporrectodea terrestris (Savigny 1826): i) 30 individuals used preferentially existing conspecifics galleries, ii) individual velocity increased 31 after each dispersal event, and iii) the lag time before each dispersal event did not seem to be 32 influenced by previous dispersers. Therefore, dispersal seems to be facilitated by 33 conspecifics' activity, which strongly supports the hypothesis of a feedback between 34 ecosystem engineers' activity and their dispersal speed.

38 Keywords: Cineradiography; X-ray Imagery; Conspecific facilitation; Dispersal behaviour; 39 Earthworms activity; Ecosystem engineering. 
Introduction

Earthworms have a profound influence on soil physical and chemical properties (Zhang and

Schrader 1993; Blanchart et al. 1999). Consequently, they play a central role in soil

functioning and in plant growth (Lee 1985; Edwards and Bohlen 1996; Scheu 2003). Their impacts on soil functioning and soil biota through the engineering of their physical environment have been the subject of a large number of studies. In contrast, there is little information available on the consequences of the potential feedback of these activities on their own life condition, although this is expected to play an important role in earthworm ecology and activity (Odling-Smee 1995; Mathieu et al. 2010). We now need to grasp these feedbacks in order to understand the driving factors of earthworm activity and spatial distribution. Here, we propose to explore the potential feedback between the construction of galleries and the dispersal speed of earthworms in the soil. habitats and the exploitation of spatially and temporally variable resources (Ronce 2007). Active dispersal of animals (opposed to passive dispersal, where individuals are transported by an external agent) involves three successive behavioural stages: departure from a breeding site, crossing to a new place, and settlement (Clobert et al. 2001; 2009). A recurrent finding of evolutionary models is that dispersal rate depends on the balance between the costs and benefits of dispersal (Bowler and Benton 2005), which are strongly determined by environmental factors (e.g. habitat quality, habitat fragmentation, patch size, density, predation) and individual life traits (e.g. age, hormonal levels, (Bonte et al. 2006; Schtickzelle et al. 2006)). In consequence, strategies that reduce these costs, such as the capacity to use cues based on conspecifics and/or environmental conditions were selected over evolutionary 
66

Materials and methods

previous studies suggest it might exist (Mathieu et al. 2010; Zirbes et al. 2010; 2012). It was noticed that the products of engineering activities, such as burrows, might be used as cues by earthworms to evaluate the state of the environment.

their dispersal behaviour was questioned. For instance, Mathieu et al (2010) showed that earthworm dispersal rate, during the departure stage, could be reduced when individuals were inoculated in a soil that was pre-used by conspecific individuals - which were no longer present - showing that earthworms can detect the former activity of conspecifics. Other studies showed that anecic earthworms use the galleries of conspecific individuals or of other species, but not specifically for dispersal (Capowiez 2000; Bastardie et al. 2003). These observations raise the question of the influence of earthworm activities on the speed of their movement during the second stage of dispersal (crossing stage).

activities and their dispersal rate by addressing three questions: i) do individuals use preferentially pre-existing conspecific galleries to disperse? ii) does dispersal velocity increase in a soil where conspecific already dispersed? and iii) is dispersal triggered by the departure of previous dispersers (like in a collective movement)? To answer these questions we developed a new technique based on X-rays imagery that allows to take pictures of earthworms in the soil, and to quantify their behaviour. 
We used the species Aporrectodea terrestris (Savigny 1826), more commonly called Aporrectodea giardi (Ribaucourt 1901), an anecic species (size: 130-170mm; mean weight: $3.3 \pm 0.9 \mathrm{~g}$ ), which lives in the soil and feeds on surface litter (Bouché 1972, 1977). Adult earthworms were collected in North of France $\left(49^{\circ} 27^{\prime} \mathrm{N}, 1^{\circ} 4^{\prime} \mathrm{E}\right)$ and were kept in suitable soil (see below) at low density (1.5 individuals per litre of soil), at $15^{\circ} \mathrm{C}$ during the day and $10^{\circ} \mathrm{C}$ at night. All earthworms were used once and were adult during the experiments. To overcome the problem of transparency of worms to X-rays and to have an accurate tracking point, we tagged individuals subcutaneously with a rod of lead of $2 \mathrm{~mm}$. Tags do not affect the growth of earthworms (Butt and Lowe 2007). Preliminary tests comparing dispersal behaviour between tagged and control individuals (not tagged) showed no effect on dispersal response (unpublished data).

$$
\text { unsuitable soil consisted in a very sandy soil with low } \mathrm{pH} \text { (Table 1) collected in an area }
$$
deprived of earthworms in the forest of Fontainebleau, France $\left(48^{\circ} 24^{\prime} \mathrm{N}, 2^{\circ} 44^{\prime} \mathrm{E}\right)$. The suitable soil (Table 1) contained more organic matter and clay than the unsuitable soil and was sampled in a grassland of the IRD research centre of Bondy, France (48 $\left.54^{\prime} \mathrm{E}, 2^{\circ} 29^{\prime} \mathrm{N}\right)$. Both soils were air dried, sieved at $2 \mathrm{~mm}$ and rewetted manually to $25 \%$ of humidity (on a massic basis). The preference of earthworms for the suitable compared to the unsuitable soil was tested in a previous experiment (Mathieu et al. 2010). Mathieu et al. (2010). Mesocosms consisted of dispersal corridor of $100 \mathrm{~cm}$ long, $20 \mathrm{~cm}$ wide and $20 \mathrm{~cm}$ height. They were composed of three equal parts (Figure 1): (1) the inoculation section, which was filled with unsuitable soil; (2) the intermediate "crossing section", 
115 composed of unsuitable soil, (3) the arrival section composed of suitable soil. All soils were

116 disposed at density of $1 \pm 0.1 \mathrm{~g} . \mathrm{cm}^{-3}$. This setup triggered dispersal as individuals tend to

117 disperse from habitats of low quality (Mathieu et al. 2010). It allows reproducing the three

118 stages of dispersal: departure, crossing and settlement in a suitable site (Clobert et al. 2009).

119 Earthworms were filmed in the crossing section, which was thinned by $40 \%$ to allow

120 earthworms detection by X-rays. Each experimental unit was closed over by a tarp, to keep

121 humidity and to prevent worms to escape. The experiment was replicated 5 times with

122 different experimental units and different individuals each day.

In each replicate, 10 individuals were inoculated at the same time in the inoculation section (Figure 1). In order to prevent any contact between individuals during the inoculation, we ensured that each individual was inoculated at a sufficient distance from the others (10 different locations distant from at least $5 \mathrm{~cm}$ from each others), and we checked that all individuals entered in the ground (on average, five minutes).

131 Diagnostic C generator with a Basler A $504 \mathrm{~K}$ with digital video camera recorder), which 132 could not moved. The X-rays were generated at $1.6 \mathrm{~mA}$ and $54.0 \mathrm{kV}$, which allowed seeing 133 the worms in the soil within a $20 \mathrm{~cm}$ radius. After inoculation of the 10 earthworms, 134 snapshots of the first $20 \mathrm{~cm}$ (in length) of the crossing section were taken (Figure 1) every 135 minute during 12 hours. Dispersal events occurred without any artificial stimulation, which 136 could have disturbed the dispersal behaviour of earthworms. In consequence we observed at 137 most 3 passages in each replicate. 
142 galleries in the soil, and to measure their dispersal velocity as well as the lag time between

143 subsequent passages of individuals within replicates. For each individual, we determined the

144 entrance and exit time in the observed section (approximately $315 \mathrm{~cm}^{2}$ ), which was centered

145 on the crossing section. The velocity (V) was determined by the ratio between the travelled

146 distance and the time required to travel over the corresponding distance. The difference of

147 time between the moment where a worm left the observed section and the moment the next

148 conspecific entered was used to calculate the lag time between two crossing events. The ratio

$149 \mathrm{Vn}+1 / \mathrm{Vn}$ between the velocity during the passage $\mathrm{n}+1$ and during the passage $\mathrm{n}$ was used to

150 quantify the relative change in the dispersal velocity. We evaluated the link between the

151 different components of dispersal behaviour (movement speed and lag time between dispersal

152 events) and the order of passage or to the presence/absence of gallery with a linear regression

153 model. All analyses and graphs were performed with the software R (Ihaka and Gentleman

154 1996).

155

156 Results and discussion

157 Despite the low number of dispersal events, we can clearly see that after the first crossing 158 event, a majority ( $84 \%$ in the second dispersal event and $100 \%$ in the third) of the new 159 dispersers used a gallery already built, rather than burrowing a new one. One individual

160 started a new gallery but ended up in an existing gallery.

161

162 Our results showed a striking increase of dispersal velocity due to previous

163 earthworm's activities. We observed a significant increase of dispersal velocity along the

164 sequence of dispersal events (linear regression $r^{2}=0.58$, $p$-value $=0.002$, Figure 2 ): during the 
165 gallery construction phase (see the attached accelerated video file about gallery construction), 166 the average velocity was $0.6 \pm 0.3 \mathrm{~cm} \cdot \mathrm{min}^{-1}$, which was the lowest speed observed. This result

167 can be related to the low colonization rate of non-inhabited or previously tilled plots usually 168 observed in the field (Butt et al. 1995; Nuutinen et al. 1997; 2006; Grigoropoulou and Butt 169 2010; Eijsackers 2011). Our observations of dispersal velocity are well above observations 170 made in earthworm-free soils (Eijsackers 2011), reporting colonization rate of 5-8 m.year ${ }^{-1}$ for 171 Aporrectodea longa and 1.5-4 m.year ${ }^{-1}$ for Lumbricus terrestris. however comparison

172 between our results in experimental device to these field observations must be done with

173 caution due to the differences in environmental conditions (spatial and temporal

174 heterogeneity, weather, interspecific interactions), in scale (1 m versus a few $\mathrm{km})$ and in the 175 length of observation (12 hours versus years). However, our results provide new insights in 176 the understanding of dispersal mechanisms of earthworms. Indeed, our observations supply 177 evidences of the capabilities of earthworms to move faster than expected from field 178 observations. Average velocity of second dispersal events was three times faster $\left(1.8 \pm 0.7 \mathrm{~cm} \cdot \mathrm{min}^{-1}\right)$ than during the first one. This result can be explained by the fact that moving in existing galleries requires much less efforts than moving in a pristine soil, as no burrowing work is required (Ehlers 1975; Edwards and Lofty 1980; Hirth et al. 1997). During the third passage,

184 earthworms exclusively used existing galleries, and the average velocity was then even higher $185\left(4.5 \pm 2.8 \mathrm{~cm} \cdot \mathrm{min}^{-1}\right)$, than during the first and second dispersal events. This can hardly be explained by a decrease of burrowing costs, because they are low during the second and third

187 dispersal events. This suggests that the observed increase in dispersal velocity along dispersal sequence should be triggered by another mechanism. Non-selective detection of conspecific activity, like detection of empty spaces in the soil, would result only in the preferred use of 
conspecifics' galleries. It cannot explain the increase in speed between the second and third

191 dispersal events. The most parsimonious explanation for this increase in speed is the

192 retrieving of cues related to conspecifics' activity or presence, such as chemical cue (Schmidt

193 Jr 1955; Ressler et al. 1968; Jiang et al. 1990). These cues could be non specific by-products

194 of earthworms' transit in the galleries (like urea, faeces or the results of the interaction

195 between mucus, microflora and soil on the walls of the galleries (Pan et al. 2010) or less

196 likely, could be specific molecules like pheromones, like in ants (Dorigo et al. 1996).

197

198

199
The lag time between two consecutive passages was apparently not influenced by the presence of galleries or the number of previous departures ( $\mathrm{p}$-value $=0.5$, Linear Model). Therefore it seems that dispersal was not induced by the existence of galleries or by social interactions during the departure of conspecifics, in contrast to previous observations (Zirbes et al. 2010).

\section{Conclusion}

Our results show that earthworm dispersal movements are much faster in areas previously engineered (i.e. burrowed) by conspecifics. Individuals selectively follow existing galleries rather than building new galleries, raising the question of the mechanisms involved in the localization of the galleries. This shows that earthworms' dispersal in soil is facilitated by their own activity, highlighting the existence of a feedback between engineering activities and dispersal velocity. It would be interesting to determine if this feedback is accidental (not specific, like autogenic engineers (Jones et al. 1994; Jouquet et al. 2006) or intended. Finally, our findings ask the question about the potential role of dispersal facilitation in community dynamic of earthworms, and the influences of this facilitation between different earthworm 
214 species or ecological categories, especially regarding colonization pattern of new habitats 215 (Uvarov 2009; Eijsackers 2011).

216

217 5. Acknowledgement

218 This work was funded by the French National Research Agency (ANR) as a part of the 219 project EDISP no. ANR-08-JCJC-0023. We would like to thank the Centre IRD Ile de France 220 and specifically Corinne Rouland-Lefèvre for access to the climatic room and to the park. A 221 great thank to Sébastien Barot, Manuel Blouin, Lise Dupont and Hélène Dudeck for their 222 help. Gaël Caro was supported by a French grant Ph.D. from the Ministère de la Recherche. 
232 Bastardie F, Capowiez Y, de Dreuzy JR, Cluzeau D (2003) X-ray tomographic and hydraulic characterization of burrowing by three earthworm species in repacked soil cores. Appl

Blanchart E, Albrecht A, Alegre J, Duboisset A, Gilot C, Pashanasi B, Lavelle P, Brussaard L (1999) Effects of earthworms on soil structure and physical properties. Earthworm manag in trop agro. Wallingford.

Bonte D, Borre JV, Lens L, Jean-Pierre M (2006) Geographical variation in wolf spider dispersal behaviour is related to landscape structure. Anim Behav 72:655-662.

Bouché MB (1972) Lombriciens de France, écologie et systématiques. INRA, Paris.

Bouché MB (1977) Strategies lombriciennes. Ecol Bull:122-132.

Bowler DE, Benton TG (2005) Causes and consequences of animal dispersal strategies: relating individual behaviour to spatial dynamics. Biol Rev 80:205-225.

Butt KR, Frederickson J, Morris RM (1995) An earthworm cultivation and soil inoculation technique for land restoration. Ecol Eng 4:1-9.

Butt KR, Lowe CN (2007) A viable technique for tagging earthworms using visible implant elastomer. Appl Soil Ecol 35:454-457.

Capowiez Y (2000) Differences in burrowing behaviour and spatial interaction between the two earthworm species Aporrectodea nocturna and Allolobophora chlorotica. Biol Fertil Soils 30:341-346. 
251 Clobert J, Danchin E, Dhondt AA, J.D. N (2001) Dispersal. Oxford University press.

252 Clobert J, Le Galliard JF, Cote J, Meylan S, Massot M (2009) Informed dispersal, 253 heterogeneity in animal dispersal syndromes and the dynamics of spatially structured populations. Ecol Lett 12:197-209.

255 256

Dorigo M, Maniezzo V, Colorni A (1996) Ant system: Optimization by a colony of cooperating agents. IEEE Trans on Sys Man and Cyber Part B-Cyber 26:29-41.

Edwards CA, Bohlen PJ (1996) Biology and Ecology of earthworms. Chapman and Hall, London.

Edwards CA, Lofty JR (1980) Effects of earthworm inoculation upon the root growth of direct drilled cereals. J Appl Ecol 17:533-543.

Ehlers W (1975) Observations on earthworm channels and infiltration on tilled and untilled loess soil. Soil Science 119:242-249.

Eijsackers H (2011) Earthworms as colonizers of natural and cultivated soil environments. Appl Soil Ecol 50:1-13.

Grigoropoulou N, Butt KR (2010) Field investigations of Lumbricus terrestris spatial distribution and dispersal through monitoring of manipulated, enclosed plots. Soil Biol Biochem 42:40-47.

Hirth JR, McKenzie BM, Tisdall JM (1997) Do the roots of perennial ryegrass elongate to biopores filled with the casts of endogeic earthworms? Soil Biol Biochem 29:529-531.

Ihaka R, Gentleman R (1996) R: A language for data analysis and graphics. J Comput Graph Stat 5:299-314. 
Jiang XC, Inouchi J, Wang D, Halpern M (1990) Purification and characterization of a chemoattractant from electric shock-induced earthworm secretion, its receptor binding, and signal transduction through the vomeronasal system of garter snakes. J Biol Chem 265:8736-8744.

Jones CG, Lawton JH, Shachak M (1994) Organisms as ecosystem engineers. Oikos 69:373386.

Jouquet P, Dauber J, Lagerl $\sqrt{ } \partial f$ J, Lavelle P, Lepage M (2006) Soil invertebrates as ecosystem engineers: Intended and accidental effects on soil and feedback loops. Appl Soil Ecol 32:153-164.

Lee KE (1985) Earthworms: Their ecology and relationship with soil and land use. Academic Press, Sydney.

Mathieu J, Barot S, Blouin M, Caro G, Decaëns T, Dubs F, Dupont L, Jouquet P, Nai P (2010) Habitat quality, conspecific density, and habitat pre-use affect the dispersal behaviour of two earthworm species, Aporrectodea icterica and Dendrobaena veneta, in a mesocosm experiment. Soil Biol Biochem 42:203-209.

Nuutinen V, Nieminen M, Butt KR (2006) Introducing deep burrowing earthworms (Lumbricus terrestris L.) into arable heavy clay under boreal conditions. Eur J Soil Biol 42:S269-S274.

Nuutinen V, Pitkänen J, Kuusela E, Widbom T, Lohilahti H (1997) Spatial variation of an earthworm community related to soil properties and yield in a grass-clover field. Appl Soil Ecol 8:85-94. 
Odling-Smee FJ (1995) Niche construction, genetic evolution and cultural change. Behav Proc 35:195-205.

Pan X, Song W, Zhang D (2010) Earthworms (Eisenia foetida, Savigny) mucus as 296 complexing ligand for imidacloprid. Biol Fertil Soils 46:845-850.

297 Ressler RH, Cialdini RB, Ghoca ML, Kleist SM (1968) Alarm pheromone in the earthworm 298 Lumbricus terrestris. Science 161:597-599.

Ronce O (2007) How does it feel to be like a rolling stone? Ten questions about dispersal evolution. Annu Rev Ecol, Evol Syst 38:231-253.

Scheu S (2003) Effects of earthworms on plant growth: patterns and perspectives: The 7th international symposium on earthworm ecology $\cdot$ Cardiff $\cdot$ Wales $\cdot 2002$. Pedobiologia 47:846-856.

304 Schmidt Jr H (1955) Behavior of two species of worms in the same maze. Science 121:341305 342.

306 Schtickzelle N, Mennechez G, Baguette M (2006) Dispersal depression with habitat fragmentation in the bog fritillary butterfly. Ecology 87:1057-1065.

Uvarov AV (2009) Inter- and intraspecific interactions in lumbricid earthworms: Their role for earthworm performance and ecosystem functioning. Pedobiologia 53:1-27. of soil aggregates. Biol Fertil Soils 15:229-234. 
312 Zirbes L, Brostaux Y, Mescher M, Jason M, Haubruge E, Deneubourg J-L (2012) SelfAssemblage and Quorum in the Earthworm Eisenia fetida (Oligochaete, Lumbricidae). PLoS One 7:e32564.

315 Zirbes L, Deneubourg JL, Brostaux Y, Haubruge E (2010) A new case of consensual 316 decision: collective movement in earthworms. Ethology 116:546-553. 
325 Table 1: Selected properties of the used soils in the experiments.

326

$\begin{array}{llc} & \text { Unsuitable } \\ \text { Soil Properties (Unit) } & \text { Soil } & \text { Suitable Soil } \\ \text { Clay (\%) } & 4.7 & 15.7 \\ \text { Silt (\%) } & 18.5 & 13.4 \\ \text { Sand (\%) } & 76.8 & 70.9 \\ \text { Organic C }\left(\mathrm{g} \mathrm{kg}^{-1}\right) & 8.5 & 28.1 \\ \left.\text { Total N (g kg }{ }^{-1}\right) & 0.33 & 2.61 \\ \text { C:N } & 25.8 & 10.8 \\ \text { Organic Matter }\left(\mathrm{g} \mathrm{kg}^{-1}\right) & 14.6 & 48.6 \\ \text { pH } & 3.8 & 7.5 \\ \text { CEC (Metson) }\left(\mathrm{cmol} \mathrm{kg}^{-1}\right) 2.9 & 11.7\end{array}$


Figure captions

338

339 Figure 1: Experimental design of the study (100 cm long; $20 \mathrm{~cm}$ wide; $20 \mathrm{~cm}$ height, $8 \mathrm{~cm}$ 340 height for the thinned section); Grey area $=$ unsuitable soil; White area $=$ suitable soil. The 341 clearest circle represents the observed area. Each triangle represents an inoculation point, 342 where a single earthworm was introduced. Arrows represent the section observed by X-rays, 343 which have been captured by a camera. A dashed arrow symbolizes the direction of 344 movement.

346 Figure 2: Individuals' dispersal velocity $\left(\mathrm{cm} \cdot \mathrm{min}^{-1}\right)$ according to their rank of passage during 347 the dispersal sequence. A line links earthworms belonging to the same mesocosm. The dashed 348 line represents the linear regression. 
362 Figures

363

$364 \quad$ Figure 1

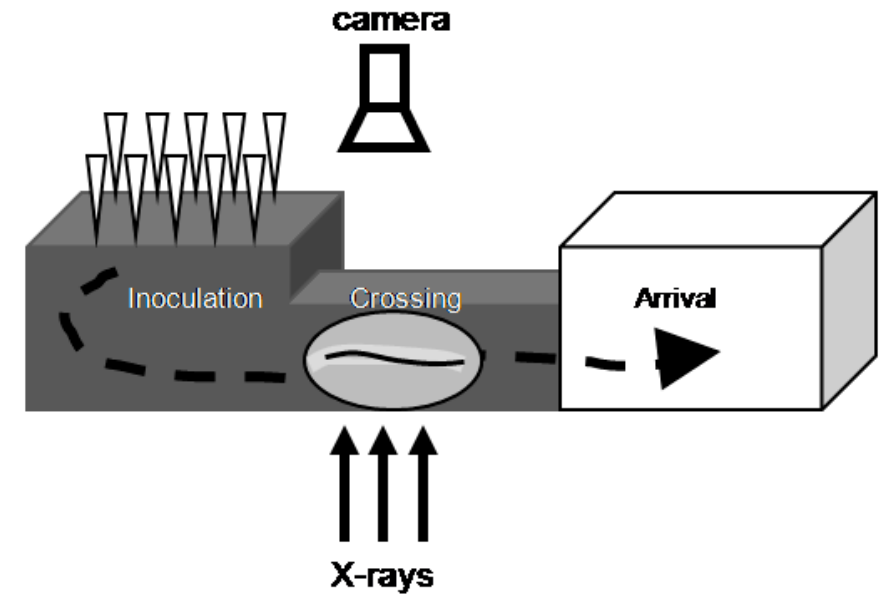

365

366

367

368

369

370

371

372

373

374

375

376

377

378

379

380 
381 Figure 2

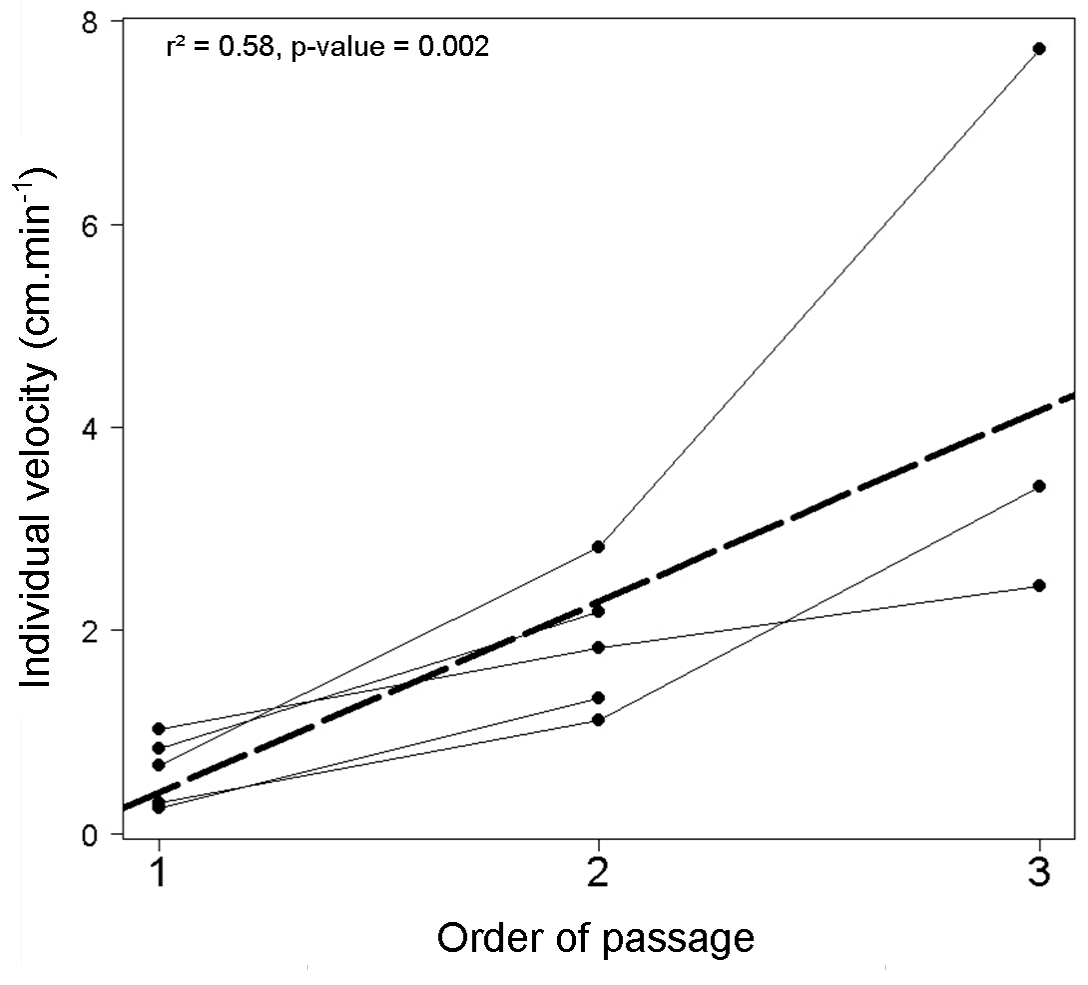

383

384

385

386

387

388

389

390 